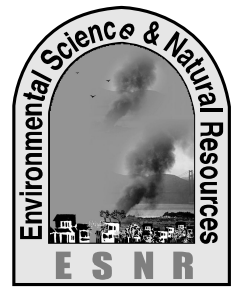

J. Environ. Sci. \& Natural Resources, 5(1): 39 - 45, 2012

ISSN 1999-7361

\title{
Influence of Commercially Available Organic vs Inorganic Fertilizers on Growth Yield and Quality of Carrot
}

\author{
H. M. Zakir, M. N. Sultana and K. C. Saha \\ Department of Agricultural Chemistry \\ Bangladesh Agricultural University, Mymensingh
}

\begin{abstract}
An experiment was conducted at the Horticulture Farm, Bangladesh Agricultural University, Mymensingh to evaluate the response of Biomeal, a commercial organic fertilizer in combination with inorganic fertilizers on growth, yield and quality named of carrot. The maximum gross yield $\left(29.27 \mathrm{t} \mathrm{ha}^{-1}\right)$ of carrot was obtained from $\mathrm{T}_{4}$ treatment [recommended dose of inorganic

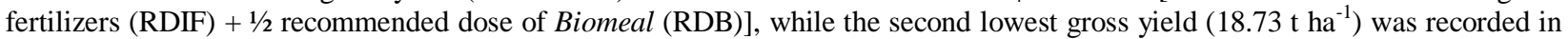
alone RDB treatment. Carrot plants treated with RDIF showed the highest values for fresh weight of individual root (67.13 $\mathrm{g}$ ), marketable yield $\left(18.74 \mathrm{t} \mathrm{ha}^{-1}\right)$, shoot length $(47.87 \mathrm{~cm})$, individual root diameter $(10.91 \mathrm{~mm})$ and nitrogen content in carrot $(2.48 \%)$. Among the biochemical properties, the maximum amount of reducing sugar and total sugar $(5.15$ and $10.51 \%$, respectively) were obtained from $\mathrm{T}_{7}$ treatment $(\mathrm{RDIF}+\mathrm{RDB})$. In context of carotene, the highest amount $(4.92 \%)$ was found in $\mathrm{T}_{4}$ treatment (RDIF + 1/2 RDB). Considering major nutrients and biochemical properties of carrot, it can be inferred that Biomeal alone is not sufficient enough but it has positive influence when it is applied in combination with inorganic fertilizers. The study also revealed that there was no significant contribution of Biomeal to increase organic carbon, N, P, S and Ca content in post harvest soils.
\end{abstract}

Keywords: Carrot, Organic fertilizer (Biomeal), Organic matter, Quality, Yield

\section{Introduction}

Both manures and fertilizers have a potential role on crop growth and development. But indiscriminate use of inorganic fertilizer changes physical, chemical and biological properties of soil as well as reduces the fertility status of soil. On the other hand, organic matter content of in the soil of Bangladesh is below $1 \%$ in about $60 \%$ of cultivable lands compared to an ideal minimum value of $3 \%$ (Islam, 2006). Now it is well agreed that depleted soil fertility is a major constraint for higher crop production in Bangladesh and indeed, yield of several crops are declining in some soils (Bhuiyan, 1998). Maintenance of soil fertility is a prerequisite for long term sustainable agriculture and organic manures play a vital role in maintaining soil fertility and crop production. Organic fertilizers are prepared from the decomposition of any product of plant and/or animal origin as long as the raw materials are not collected from unsafe sources (such as industrial waste, toxic waste, hospital waste etc.). In Bangladesh, although organic fertilizer production is a promising sector, but unfortunately, it is not produced and used on a large scale.

Recycling of crop residues and organic wastes through composting is the key technology for production of organic fertilizers (Rao et al., 2008). Disposal of ever- increasing amount of urban and agricultural wastes is becoming a serious problem in
Bangladesh. Recently different companies of Bangladesh come forward to produce organic fertilizer by using different types of urban and agricultural wastes, Biomeal is one of them. This technology may help us to reduce environmental pollution as well as to provide quality soil amendments/ conditioners. On the other hand, practicing organic fertilizer may reduce the demand of chemical fertilizers, which can save a huge amount of foreign currency. Before recommending to practice, it is necessary to confirm about the quality as well as the efficacy by conducting research under different AEZs of Bangladesh. Recently, the Ministry of Agriculture fixed the criteria for organic manures. So, it is imperative to evaluate Biomeal as a source of commercially available organic fertilizer. Considering the above facts the present study was undertaken with the objectives to evaluate the impact of Biomeal vs inorganic fertilizers on growth, yield and quality of carrot, and nutrient status in post harvest soils.

\section{Materials and Methods}

\section{Experimentation}

The experiment was carried out at the Horticulture Farm, Bangladesh Agricultural University (BAU), Mymensingh, during the period from November 2009 to February 2010. The organic fertilizer, Biomeal was collected from the local market (marketed by the Corbel International Limited, Dhaka, Bangladesh, 
Batch \# 00906). Total concentrations of major nutrients in Biomeal are presented in Table 1. The experimental site was silt loam soil. Previously T. aman rice was cultivated in the field before laying out of present experiment. The experiment was conducted on well prepared plots according to randomized complete block design (RCBD) with three replications. The size of each unit plot was $4 \mathrm{~m} \times 2.5$ $\mathrm{m}$ and the total numbers of plots were 24 by considering eight treatments. The treatments werecontrol $\left(\mathrm{T}_{0}\right)$, recommended dose of inorganic fertilizers (RDIF) (197.6, 148.2, 148.2 and $98.8 \mathrm{~kg}$ $\mathrm{ha}^{-1}$ urea, TSP, MOP and gypsum, respectively) $\left(\mathrm{T}_{1}\right)$, recommended dose of Biomeal (RDB) $\left(6 \mathrm{t} \mathrm{ha}^{-1}\right)\left(\mathrm{T}_{2}\right)$, $1 / 2 \mathrm{RDIF}+1 / 2 \mathrm{RDB}\left(\mathrm{T}_{3}\right), \mathrm{RDIF}+1 / 2 \mathrm{RDB}\left(\mathrm{T}_{4}\right), 1 / 4$ $\mathrm{RDIF}+\mathrm{RDB}\left(\mathrm{T}_{5}\right), 1 / 2 \mathrm{RDIF}+\mathrm{RDB}\left(\mathrm{T}_{6}\right)$ and RDIF +
$\operatorname{RDB}\left(\mathrm{T}_{7}\right)$. The test crop was carrot (Daucuscarota L.) cv. New Kuroda. Total amount of TSP, gypsum and Biomeal were applied to the individual plots during final land preparation according to the treatments used. Urea and MOP were applied in three equal splits: first split was applied at final land preparation, second one was at 15 days after seed sowing and the third split was applied at 35 days after seed sowing. Intercultural operation was done as per necessary. Thinning was carried out after complete germination so as to have uniform plant distance. Data were recorded on plant height, shoot and root lengths, diameter of root, fresh weight of shoot and root, shoot and root dry weights, percent branched and cracked roots, and gross and marketable yield of carrot.

Table 1. Major nutrients status in Biomeal

\begin{tabular}{|cccccc|}
\hline $\mathrm{N}(\%)$ & $\mathrm{P}\left(\mu \mathrm{g} \mathrm{g}^{-1}\right.$ soil $)$ & $\mathrm{K}_{\left(\mathrm{cmol} \mathrm{kg}^{-1} \text { soil }\right)}$ & $\mathrm{S}\left(\mu \mathrm{g} \mathrm{g}^{-1}\right.$ soil $)$ & $\mathrm{Ca}(\%)$ & $\mathrm{Mg}(\%)$ \\
\hline 0.36 & 0.17 & 0.16 & 0.11 & 2.5 & 10.9 \\
\hline
\end{tabular}

\section{Analysis of soil}

The chemical analyses of soil were accomplished in the laboratory of the Department of Agricultural Chemistry, Bangladesh Agricultural University (BAU). Chemical properties and nutrient contents (Organic carbon, N, P, K, Ca, Mg and $\mathrm{S}$ ) in soil samples were determined based on procedures outlined by Ghosh et al., 1983; Page et al., 1982 and Olsen et al., 1954.

\section{Analysis of carrot}

Carotene, vitamin $\mathrm{C}$, reducing sugar and total sugar content in carrot were determined at the Post Harvest Technology section, Horticulture Research Centre, Bangladesh Agricultural Research Institute (BARI), Gazipur based on the methods as described by AOAC (2000) and Ranganna (1991). Nutirents content (N, P, $\mathrm{K}, \mathrm{S}, \mathrm{Ca}$ and $\mathrm{Mg}$ ) in carrot samples were determined in the laboratory of the Department of Agricultural Chemistry, BAU by adopting the procedures outlined by Page et al., 1982; Olsen et al., 1954 and Tandon, 1995.

\section{Statistical analysis}

Analysis of variance was done with the help of computer package MSTAT developd by Russel (1986). The test LSD was used to get the significant difference among the treatments means.

\section{Results and Discussion}

\section{a) Effect of Biomeal and inorganic fertilizers on growth and yield of carrot}

Effect of Biomeal and inorganic fertilizers on fresh and dry weight and length of shoot were significant at $1 \%$ level of probability over $\mathrm{T}_{0}$ (control) and $\mathrm{T}_{2}$ (recommended dose of Biomeal) treatments. All these growth parameters showed best performance, where $100 \%$ or $50 \%$ of inorganic fertilizers were applied (i.e. the treatments $T_{1}, T_{3}, T_{4}, T_{6}$ and $T_{7}$ ) and the lowest were in control. It is also found from Table 2 that application of Biomeal and inorganic fertilizers alone or in combination significantly increased fresh and dry weight of root. On the other hand, the lowest fresh and dry weight, length and diameter of root were recorded from control and $T_{2}$ treatment, respectively (Table 2). This result is consistent with the findings of Sunanda and Mallareddy (2007), they reported that vermicompost, neem cake and FYM (farm yard manure) combined with 50 and $100 \%$ recommended dose of NPK were superior in terms of root length of carrot. The results obtained from the present study indicate that the application of Biomeal alone is not sufficient enough for proper growth of carrot shoot. A similar observation was also reported by Vijayakumari et al. (2009) from a study on the effect of few eco-friendly manures on the growth attributes of carrot. 
The highest gross yield of carrot $\left(29.27 \mathrm{t} \mathrm{ha}^{-1}\right)$ was obtained at $\mathrm{T}_{4}$ treatment (RDIF $+1 / 2$ RDB) followed by $\mathrm{T}_{7}, \mathrm{~T}_{1}, \mathrm{~T}_{3}, \mathrm{~T}_{6}$ and $\mathrm{T}_{5}$, and all of which were statistically identical (Table 2). On the other hand, the lowest gross yield was obtained at control (15.00 tha $\left.{ }^{1}\right)$ and the second lowest gross yield $\left(18.73 \mathrm{tha}^{-1}\right)$ was produced by the treatment $\mathrm{T}_{2}$ (recommended dose of Biomeal). This result also suggests that only Biomeal application is not sufficient enough for better growth and yield of carrot might be due to inadequate supply of major nutrients (Table 1). Similar observation was also reported by Alom (2004), who conducted an experiment with treatments comprising organic and inorganic fertilizers and found the highest gross yield $\left(67.47 \mathrm{t} \mathrm{ha}^{-1}\right)$ from the treatment of inorganic fertilizers + mustard oil cake (MOC) (@290 kg urea $+225 \mathrm{TSP}+250 \mathrm{~kg} \mathrm{MP}+5$ ton MOC ha $\left.{ }^{-1}\right)$. On the other hand, Sharma et al. (2003) reported that the application of 50\% NPK was superior to the fertilizer combinations in terms of root yield of carrot. On the contrary, Pimentel et al. (2009) conducted a field experiment in Brazil to evaluate the agronomic yield of carrot after application of organic manure and reported that the yield was most responsive to the application of organic compost.

The highest amount of marketable yield $\left(18.74 \mathrm{t} \mathrm{ha}^{-1}\right)$ of individual root was found in the treatment $T_{1}$ (recommended dose inorganic fertilizers) followed by $\mathrm{T}_{3}, \mathrm{~T}_{4}, \mathrm{~T}_{5}, \mathrm{~T}_{6}, \mathrm{~T}_{2}$ and control (Table 2). It is also be seen from the Table 2 that $\mathrm{T}_{7}$ treatment produced the lowest marketable yield $\left(12.19 \mathrm{t} \mathrm{ha}^{-1}\right)$, due to the highest amount of branched roots. The highest amount of branched root $(0.91 \%)$ and cracked root $(0.69 \%)$ were obtained from the treatments $\mathrm{T}_{7}$ and $\mathrm{T}_{1}$, respectively. This result indicates that application of higher amount of inorganic fertilizers alone or in combination with Biomeal negatively influenced the marketable yield of carrot root. Bender et al. (2009) reported that marketable yield of organic carrots was $11 \%$ higher than that of conventionally grown carrots with the application of chemical fertilizers (N 115, P 40 and $\mathrm{K} 152 \mathrm{~kg} \mathrm{ha}^{-1}$ ) and pesticides. But present research finding differs with this result which might be due to poor quality of applied organic manure

\section{b) Effect of Biomeal and inorganic fertilizers on nutrient contents and biochemical properties of carrot}

Nutrient contents in carrot significantly varied due to the application of different doses of Biomeal, inorganic fertilizers and their combinations (Table 3). The highest concentration of nitrogen $(2.48 \%)$ in carrot was obtained at treatment $\mathrm{T}_{1}$, which was statistically identical with $\mathrm{T}_{2}, \mathrm{~T}_{0}, \mathrm{~T}_{3}$ and $\mathrm{T}_{6}$ treatments. The highest content of $\mathrm{P}(0.39 \%), \mathrm{K}$ $(0.33 \%)$ and $\mathrm{Ca}(0.98 \%)$ in carrot were recorded from the treatment $\mathrm{T}_{5}(1 / 4 \mathrm{RDIF}+\mathrm{RDB})$ and the lowest were found in $T_{1}, T_{7}$ and $T_{2}$ treatments, respectively. This result indicates that application of full dose of inorganic fertilizers alone or in combination with Biomeal negatively influenced on phosphorus and potassium content in carrot. Magnesium $(0.62 \%)$ and sulphur $(0.16 \%)$ content was highest in $\mathrm{T}_{7}$ and $\mathrm{T}_{6}$ treatments, respectively where full dose of Biomeal was applied along with 100 and $50 \%$ of recommended doses of inorganic fertilizers.

The application of Biomeal, inorganic fertilizers and their combination on biochemical properties (i.e. reducing sugar, total sugar, vitamin $\mathrm{C}$ and carotene) of individual carrot root was found statistically significant $(\mathrm{P} \leq 0.01)$ (Table 4). The highest amount of carotene $(4.92 \%)$ was found in treatment $\mathrm{T}_{4}$ and the lowest amount was obtained in the $\mathrm{T}_{2}$ (full dose of Biomeal), which indicate that the application of Biomeal alone is not sufficient enough for improving carotene content in carrot. Similar result is also reported by Bender et al. (2009), they also stated that the contents of $\beta$-carotene was significantly lower in organically grown carrot. The highest reducing sugar $(5.15 \%)$ and total sugar $(10.51 \%)$ contents were obtained at the treatment $\mathrm{T}_{7}$ and the lowest (2.58 and $4.29 \%$, respectively) contents were found in the treatment $\mathrm{T}_{2}$. This result indicates that the application of inorganic fertilizers along with Biomeal positively influenced on sugar contents in carrot. This result is at par with the findings reported by Yan et al. (2004). Bender et al. (2009) reported that the contents of dry matter, total sugars, soluble solids, phosphorus, potassium, calcium and magnesium were insignificant in organically grown carrot than in conventionally grown carrot. Vitamin $\mathrm{C}$ content in carrot varied from $0.05-0.14 \mathrm{mg} 100 \mathrm{~g}^{-1}$ carrot. The highest vitamin $\mathrm{C}$ content $\left(0.14 \mathrm{mg} 100 \mathrm{~g}^{-1}\right)$ was obtained at control treatment which was statistically identical to $T_{1}$ treatment (Table 4). This result indicates that reduction of vitamin $\mathrm{C}$ content occurred due to application of Biomeal alone or in combination with inorganic fertilizers. Similar result was also reported by Bender et al. (2009), and they stated that the contents of vitamin $\mathrm{C}$ and nitrogen were significantly lower in organically grown carrot than in conventionally grown carrot. 
Table 2. Effect of Biomeal and inorganic fertilizers on growth and yield of carrot

\begin{tabular}{|c|c|c|c|c|c|c|c|c|c|c|c|}
\hline Treatment & $\begin{array}{c}\text { Length } \\
\text { of shoot } \\
(\mathrm{cm})\end{array}$ & $\begin{array}{c}\text { Length } \\
\text { of root } \\
(\mathrm{cm})\end{array}$ & $\begin{array}{l}\text { Fresh } \\
\text { weight of } \\
\text { individual } \\
\text { root }(\mathrm{g})\end{array}$ & $\begin{array}{c}\text { Dry } \\
\text { weight of } \\
\text { individual } \\
\operatorname{root}(\mathrm{g})\end{array}$ & $\begin{array}{c}\text { Fresh } \\
\text { weight of } \\
\text { individual } \\
\text { shoot }(g)\end{array}$ & $\begin{array}{c}\text { Dry } \\
\text { weight of } \\
\text { individual } \\
\text { shoot }(\mathrm{g})\end{array}$ & $\begin{array}{l}\text { Diameter of } \\
\text { individual } \\
\text { root }(\mathbf{m m})\end{array}$ & $\begin{array}{l}\text { Cracked } \\
\text { root }(\%)\end{array}$ & $\begin{array}{l}\text { Branched } \\
\text { root }(\%)\end{array}$ & $\begin{array}{c}\text { Gross } \\
\text { yield of } \\
\begin{array}{c}\text { root } \\
\left.\text { ha }^{-1}\right)\end{array}(t\end{array}$ & $\begin{array}{l}\text { Marketable } \\
\text { yield of root } \\
\quad\left(\mathrm{tha}^{-1}\right)\end{array}$ \\
\hline $\mathbf{T}_{\mathbf{0}}$ & $26.90 \mathrm{~d}$ & $10.70 \mathrm{~b}$ & $34.47 \mathrm{~b}$ & $3.70 \mathrm{~d}$ & $11.33 \mathrm{~d}$ & $0.74 d$ & $7.04 b$ & $0.35 b$ & $0.39 \mathrm{c}$ & $15.00 \mathrm{c}$ & 13.88ab \\
\hline $\mathbf{T}_{1}$ & $47.87 \mathrm{a}$ & $13.29 \mathrm{ab}$ & $67.13 a$ & $8.43 \mathrm{ab}$ & $37.27 \mathrm{ab}$ & $4.31 \mathrm{a}$ & $10.91 \mathrm{a}$ & $0.69 \mathrm{a}$ & $0.75 \mathrm{ab}$ & $26.25 \mathrm{ab}$ & $18.74 \mathrm{a}$ \\
\hline $\mathbf{T}_{2}$ & $28.10 \mathrm{~d}$ & 11.10ab & $57.54 \mathrm{a}$ & $5.40 \mathrm{~b} \mathrm{c}$ & $16.26 \mathrm{~cd}$ & $1.10 \mathrm{~d}$ & $6.88 b$ & $0.58 \mathrm{ab}$ & $0.59 \mathrm{bc}$ & $18.73 b c$ & $14.79 \mathrm{ab}$ \\
\hline $\mathbf{T}_{3}$ & $36.00 \mathrm{bc}$ & $13.57 \mathrm{a}$ & $63.28 \mathrm{a}$ & $8.29 \mathrm{ab}$ & $21.51 \mathrm{c}$ & $2.29 \mathrm{c}$ & $9.67 \mathrm{ab}$ & $0.42 \mathrm{~b}$ & $0.60 \mathrm{bc}$ & $25.83 \mathrm{ab}$ & $18.50 \mathrm{ab}$ \\
\hline $\mathbf{T}_{4}$ & $41.17 \mathrm{~b}$ & $12.60 \mathrm{ab}$ & $66.23 \mathrm{a}$ & $8.64 a b$ & $31.67 \mathrm{~b}$ & $3.89 \mathrm{a}$ & $9.19 \mathrm{ab}$ & $0.46 \mathrm{~b}$ & $0.61 b c$ & $29.27 \mathrm{a}$ & $18.60 \mathrm{ab}$ \\
\hline $\mathbf{T}_{5}$ & $31.43 \mathrm{~cd}$ & $12.83 \mathrm{ab}$ & $59.47 \mathrm{a}$ & $6.69 b$ & $19.76 \mathrm{~cd}$ & $1.43 \mathrm{~d}$ & $8.76 a b$ & $0.48 \mathrm{ab}$ & $0.67 \mathrm{~b}$ & $21.67 \mathrm{abc}$ & $18.51 \mathrm{ab}$ \\
\hline$T_{6}$ & $46.87 \mathrm{a}$ & $12.43 \mathrm{ab}$ & $66.68 \mathrm{a}$ & $9.97 \mathrm{a}$ & $41.00 \mathrm{a}$ & $3.96 a$ & $8.67 b$ & $0.50 \mathrm{ab}$ & $0.53 \mathrm{bc}$ & 23.33ab & $17.50 \mathrm{ab}$ \\
\hline $\mathbf{T}_{7}$ & $37.62 b$ & $13.60 \mathrm{a}$ & $66.89 \mathrm{a}$ & $9.97 \mathrm{a}$ & $33.99 \mathrm{ab}$ & $3.19 \mathrm{~b}$ & $8.89 \mathrm{ab}$ & $0.52 \mathrm{ab}$ & $0.91 \mathrm{a}$ & 27. $54 \mathrm{a}$ & $12.19 \mathrm{~b}$ \\
\hline CV (\%) & 8.35 & 11.34 & 18.38 & 19.78 & 13.64 & 16.03 & 12.03 & 24.67 & 19.45 & 18.56 & 21.78 \\
\hline LSD & 5.40 & 2.48 & 19.26 & 3.07 & 8.64 & 0.68 & 2.17 & 0.21 & 0.21 & 7.74 & 6.51 \\
\hline $\begin{array}{c}\text { Level of } \\
\text { significance }\end{array}$ & $* *$ & $* *$ & $* *$ & $* *$ & $* *$ & $* *$ & $* *$ & * & $* *$ & $* *$ & $* *$ \\
\hline
\end{tabular}

$*$ and $* *=$ Significant at $5 \%$ and1\% level of probability, respectively. In a column, the figure(s) having same letter are not significantly different by DMRT. 
Table 3. Impact of Biomeal and inorganic fertilizers on major nutrient contents of carrot

\begin{tabular}{|c|c|c|c|c|c|c|}
\hline \multirow[t]{2}{*}{ Treatment } & \multicolumn{6}{|c|}{ Nutrient contents $(\%)$} \\
\hline & $\mathbf{N}$ & $\mathbf{P}$ & $\mathbf{K}$ & $\mathbf{S}$ & $\mathbf{C a}$ & Mg \\
\hline $\mathbf{T}_{\mathbf{0}}$ & $2.22 \mathrm{ab}$ & $0.25 \mathrm{~b}$ & $0.27 \mathrm{c}$ & $0.09 \mathrm{e}$ & $0.82 \mathrm{~b}$ & $0.30 \mathrm{~b}$ \\
\hline $\mathbf{T}_{1}$ & $2.48 \mathrm{a}$ & $0.25 \mathrm{~b}$ & $0.25 \mathrm{~d}$ & $0.12 \mathrm{~cd}$ & $0.87 b$ & $0.26 \mathrm{~b}$ \\
\hline $\mathbf{T}_{2}$ & $2.46 \mathrm{a}$ & $0.30 \mathrm{ab}$ & $0.29 b$ & $0.13 \mathrm{c}$ & $0.50 \mathrm{f}$ & $0.16 \mathrm{~b}$ \\
\hline $\mathbf{T}_{3}$ & $2.14 \mathrm{ab}$ & $0.32 \mathrm{ab}$ & $0.27 \mathrm{c}$ & $0.15 \mathrm{ab}$ & $0.73 d$ & $0.20 \mathrm{~b}$ \\
\hline $\mathbf{T}_{4}$ & $1.75 b$ & $0.29 \mathrm{ab}$ & $0.31 b$ & $0.14 b c$ & $0.74 d$ & $0.06 \mathrm{~b}$ \\
\hline $\mathbf{T}_{5}$ & $1.68 b$ & $0.39 \mathrm{a}$ & $0.33 \mathrm{a}$ & $0.11 \mathrm{de}$ & $0.98 \mathrm{a}$ & $0.10 \mathrm{~b}$ \\
\hline $\mathbf{T}_{6}$ & $1.95 \mathrm{ab}$ & $0.31 \mathrm{ab}$ & $0.30 \mathrm{~b}$ & $0.16 \mathrm{a}$ & $0.77 \mathrm{c}$ & $0.07 \mathrm{~b}$ \\
\hline $\mathbf{T}_{7}$ & $1.88 \mathrm{~b}$ & $0.34 \mathrm{ab}$ & $0.22 \mathrm{e}$ & $0.09 \mathrm{e}$ & $0.60 \mathrm{e}$ & $0.62 \mathrm{a}$ \\
\hline $\mathrm{CV}(\%)$ & 14.43 & 16.51 & 5.36 & 12.11 & 2.40 & 76.82 \\
\hline LSD & 0.52 & 0.10 & 0.02 & 0.02 & 0.02 & 0.28 \\
\hline $\begin{array}{c}\text { Level of } \\
\text { significance }\end{array}$ & $* *$ & $*$ & $* *$ & $* *$ & $* *$ & $* *$ \\
\hline
\end{tabular}

$*$ and $* *=$ Significant at $5 \%$ and $1 \%$ level of probability, respectively. In a column, the figure(s) having same letter are not significantly different by DMRT.

Table 4. Performance of Biomeal and inorganic fertilizers on biochemical properties of carrot

\begin{tabular}{|c|c|c|c|c|}
\hline Treatment & Reducing sugar $(\%)$ & Total sugar $(\%)$ & $\begin{array}{c}\text { Vitamin } C(m g \\
\left.100 g^{-1}\right)\end{array}$ & Carotene \\
\hline $\mathbf{T}_{0}$ & $4.38 \mathrm{~b}$ & $8.30 \mathrm{ab}$ & $0.14 \mathrm{a}$ & $4.18 \mathrm{~d}$ \\
\hline$T_{1}$ & $4.19 \mathrm{~b}$ & $6.58 \mathrm{~b}$ & $0.12 \mathrm{a}$ & $3.35 \mathrm{~g}$ \\
\hline $\mathbf{T}_{2}$ & $2.58 \mathrm{c}$ & $4.92 \mathrm{~b}$ & $0.07 b c$ & $3.10 \mathrm{~h}$ \\
\hline $\mathbf{T}_{3}$ & $5.03 \mathrm{ab}$ & $7.19 b$ & $0.09 \mathrm{~b}$ & $4.67 \mathrm{c}$ \\
\hline $\mathbf{T}_{4}$ & $4.63 b$ & $9.62 \mathrm{a}$ & $0.06 \mathrm{c}$ & $4.92 \mathrm{a}$ \\
\hline $\mathbf{T}_{5}$ & $4.57 \mathrm{~b}$ & $5.0 \mathrm{~b}$ & $0.05 \mathrm{c}$ & $3.68 \mathrm{f}$ \\
\hline $\mathbf{T}_{6}$ & $4.03 \mathrm{~b}$ & $6.21 \mathrm{~b}$ & $0.05 \mathrm{c}$ & $4.10 \mathrm{e}$ \\
\hline $\mathbf{T}_{7}$ & $5.15 a$ & $10.51 \mathrm{a}$ & $0.06 \mathrm{c}$ & $4.89 \mathrm{~b}$ \\
\hline CV (\%) & 12.76 & 15.86 & 0.76 & 2.31 \\
\hline LSD & 1.16 & 2.36 & 0.02 & 00.02 \\
\hline level of significance & $* *$ & $* *$ & $* *$ & $* *$ \\
\hline
\end{tabular}

** = Significant at 1\% level of probability. In a column, the figure(s) having same letter are not significantly different by DMRT.

\section{c) Effect of Biomeal and inorganic fertilizers on nutrients status of post harvest soils}

The amount of organic carbon among the samples ranged from 0.54 to 0.79 . The highest organic carbon content was found in $T_{1}$ and $T_{4}$ treatments and those were statistically identical with $T_{2}$ and $T_{3}$ treatments. While the lowest organic carbon content was obtained in $\mathrm{T}_{5}$ treatment (Table 5). It can be inferred from the results that there was no significant contribution of
Biomeal alone or in combination with inorganic fertilizers to increase organic carbon content in post harvest soils. The highest nitrogen content $(0.55 \%)$ was found in $\mathrm{T}_{5}$ treatment, which was statistically at par with all other treatments except $\mathrm{T}_{3}$. The maximum amount of available phosphorus and calcium (0.13 and $0.27 \%$, respectively) in post harvest soil was obtained from control. The highest S content $(0.30 \%)$ was contributed by $\mathrm{T}_{4}$ and that of lowest $(0.07 \%)$ in 
$T_{3}$. These results indicate that there was no significant contribution of Biomeal alone or in combination with inorganic fertilizers to increase total $\mathrm{N}$, available $\mathrm{P}$ and $\mathrm{S}$, and exchangeable $\mathrm{Ca}$ content in post harvest soils. Exchangeable $\mathrm{K}$ and $\mathrm{Mg}$ contents in post harvest soil were highest $(0.34$ and $0.47 \%$, respectively) in $\mathrm{T}_{2}$ treatment where full dose of Biomeal was applied (Table 5). From this study, it can be inferred that application of Biomeal alone or in combination with $50 \%$ of inorganic fertilizers has positive influenced on exchangeable $\mathrm{K}$ and $\mathrm{Mg}$ content in post harvest soils.

Table 5. Impact assessment of Biomeal and inorganic fertilizers application on nutrient status in post harvest soil

\begin{tabular}{|c|c|c|c|c|c|c|c|}
\hline \multirow{3}{*}{ Treatment } & \multicolumn{7}{|c|}{ Nutrients status in post harvest soil $(\%)$} \\
\hline & \multicolumn{2}{|c|}{ Total } & \multicolumn{2}{|c|}{ Available } & \multicolumn{3}{|c|}{ Exchangeable } \\
\hline & OC & $\mathbf{N}$ & $\mathbf{P}$ & $\mathbf{S}$ & $\mathbf{K}$ & $\mathbf{C a}$ & Mg \\
\hline $\mathbf{T}_{\mathbf{0}}$ & $0.60 \mathrm{bc}$ & $0.23 \mathrm{ab}$ & $0.13 \mathrm{a}$ & $0.17 \mathrm{~d}$ & $0.13 b$ & $0.27 \mathrm{a}$ & $0.24 \mathrm{ab}$ \\
\hline $\mathbf{T}_{1}$ & $0.79 \mathrm{a}$ & $0.32 \mathrm{ab}$ & $0.07 \mathrm{c}$ & $0.20 \mathrm{c}$ & $0.15 b$ & $0.19 \mathrm{bcd}$ & $0.26 \mathrm{ab}$ \\
\hline $\mathbf{T}_{2}$ & $0.70 \mathrm{ab}$ & $0.39 \mathrm{ab}$ & $0.09 b$ & $0.11 \mathrm{e}$ & $0.34 \mathrm{a}$ & $0.20 \mathrm{bc}$ & $0.47 \mathrm{a}$ \\
\hline $\mathbf{T}_{3}$ & $0.75 \mathrm{ab}$ & $0.22 b$ & $0.07 \mathrm{c}$ & $0.07 \mathrm{f}$ & $0.08 \mathrm{~b}$ & $0.16 \mathrm{de}$ & $0.20 \mathrm{~b}$ \\
\hline $\mathbf{T}_{4}$ & $0.79 \mathrm{a}$ & $0.27 \mathrm{ab}$ & $0.07 \mathrm{c}$ & $0.30 \mathrm{a}$ & $0.15 b$ & $0.21 \mathrm{~b}$ & $0.26 \mathrm{ab}$ \\
\hline $\mathbf{T}_{5}$ & $0.54 \mathrm{c}$ & $0.55 \mathrm{a}$ & $0.08 \mathrm{bc}$ & $0.26 \mathrm{ab}$ & $0.21 \mathrm{ab}$ & $0.23 \mathrm{ab}$ & $0.25 \mathrm{ab}$ \\
\hline $\mathbf{T}_{6}$ & $0.58 b c$ & $0.37 \mathrm{ab}$ & $0.07 \mathrm{c}$ & $0.24 b$ & $0.26 \mathrm{ab}$ & $0.23 \mathrm{ab}$ & $0.40 \mathrm{a}$ \\
\hline $\mathbf{T}_{7}$ & $0.60 \mathrm{bc}$ & $0.34 \mathrm{ab}$ & $0.08 b c$ & $0.25 \mathrm{ab}$ & $0.19 b$ & $0.23 b$ & $0.21 b$ \\
\hline CV (\%) & 9.34 & 76.10 & 14.90 & 12.38 & 86.63 & 10.11 & 59.05 \\
\hline LSD & 0.16 & 0.36 & 0.02 & 0.02 & 0.24 & 0.34 & 0.24 \\
\hline $\begin{array}{c}\text { Level of } \\
\text { significance }\end{array}$ & $* *$ & $*$ & $* *$ & $* *$ & $*$ & $* *$ & $* *$ \\
\hline
\end{tabular}

$*$ and $* *=$ Significant at $5 \%$ and $1 \%$ level of probability, respectively. In a column, the figure(s) having same letter are not significantly different by DMRT.

\section{Conclusions}

From the study result, it may be concluded that application of $1 / 2$ recommended dose of Biomeal along with full dose of inorganic fertilizers (i.e. treatment $\mathrm{T}_{4}$ ) performed better on the aspect of yield, yield contributing characters as well as major nutrients and biochemical properties of carrot. On the other hand, the results revealed that there was no significant contribution of Biomeal to increase organic carbon, $\mathrm{N}, \mathrm{P}, \mathrm{S}$ and $\mathrm{Ca}$ content in post harvest soils. Biomeal or other commercially available organic fertilizers should be trialed more intensively in different AEZs of Bangladesh before making a final conclusion. However, it can be inferred from the results that use of Biomeal is not sufficient enough to minimize the amount of inorganic fertilizers. The appropriate authorities should sincerely think over the matter and take necessary action while any quarter introduces any substance or compound in the market in the name of organic fertilizer so that farmers of the country are not deceived. 


\section{References}

Alom, A. 2004. Effect of organic and inorganic fertilizers on growth and yield of carrot. MS thesis. Department of Horticulture, BAU, Mymensingh, pp 40-44.

AOAC. 2000. Official Methods of Analysis of AOAC International. $17^{\text {th }}$ edn. AOAC, Washington DC, $2200 \mathrm{p}$.

Bender, I.; Ess, M.; Matt, D.; Moor, U.; Tonutare, T. and Luik, A. 2009. Quality of organic and conventional carrots. Agronomy Research, 7(2): 572-577.

Bhuiyan, N. I. 1998. Soil research in Bangladesh: past, present and future. In: Proceedings on Soil Research and Education in Bangladesh. BAU, Mymensingh, pp 6-1.

Ghosh, A.B.; Bijoy, J.C.; Hasan, R. and Singh, D. 1983. Soil and Water Testing Method. A Laboratory Manual. Division of Soil Science and Agricultural Chemistry, IARI, New Delhi, India, pp 221-226.

Islam, M.S. 2006. Use of bioslurry as organic fertilizer in Bangladesh agriculture. Prepared for the presentation at the International Workshop on the Use of Bioslurry Domestic Biogas Programme. Bangkok, Thailand.

Namasiku, M. and Oagile, D. 2010. Impact of poultry manure and its associated salinity on the growth and yield of spinach (Spinaceaoleracea) and carrot (Daucuscarota). International Journal of Agriculture and Biology, 12: 489-494.

Olsen, S.R.; Cole, C.V.; Watanabe, F.S. and Dean, L.A. 1954. Estimation of available phosphorus in soils by extraction with sodium bicarbonate. U.S. Department of Agricultural Research, 929 p.

Page, A.L.; Miller, R.H. and Keeney, D.R. 1982. Methods of Soil Analysis, Part- 2, $2^{\text {nd }}$ edn. American Society of Agronomy Inc., Medison, Washington, USA, pp 98-765.
Pimentel, M.S.; Lana, A.M.Q. and Polli, H.De. 2009. Agronomic yield in lettuce and carrot intercropped and manured with crescent doses of organic compost. Revista Ciencia Agronomica, 40(1): 106-112.

Ranganna. S. 1991. Hand Book of Analysis and Quality Control for Fruit and Vegetable Products. Tata McGraw-Hill Publishing Co. Ltd. New Delhi, India, 12 .

Rao, K.J.; Lakshmi, Ch.S.R. and Raju, A.S. 2008. Evaluation of manurial value of urban and agricultural waste composts. Journal of Indian Society of Soil Science, 54(3): 295-299.

Russel, D. F. 1986. M-STAT Director. Crop and Soil Science Dept., Michigan State University, U.S.A.

Sharma, A.; Sharma, R.P.; Sonia Sood and Sharma, J.J. 2003. Influence of integrated use of nitrogen, phosphorus, potassium and FYM on the yield attributing traits and marketable yield of carrot (Daucascarota) under high hills dry temperate conditions of Northwestern Himalayas. Indian Journal of Agricultural Sciences, 73(9): 500-503.

Sunanda, R. N. and Mallareddy, K. 2007. Effect of different organic manures and inorganic fertilizers on growth, yield and quality of carrot (Daucuscarota L.). Karnataka Journal of Agricultural Sciences, 20(3):686-688.

Tandon, H. L. S. 1995. Methods of Analysis of Soils, Plants, Waters and Fertilizers. Fertilizer Development and Consultation Organization, New Delhi, India.

Vijayakumari, B.; Hiranmaiyadav, R. and Sowmya, M. 2009. A study on the effect of few ecofriendly manures on the growth attributes of carrot (Daucuscarota L.). Journal of Environmental Science and Engineering, 51(1): 13-16.

Yan, J. W. C. Y.; Ling, S. L.; Ming, Z. X.; Chen, Z. G. and Yao, S. S. 2004. Effect of the combined application of organic manure and fertilizer on Chinese cabbage yield and quality. Journal of Jilin Agricultural University, 26(2): 155-157. 